\title{
Maintenance of spermatogenesis in hypogonadotropic hypogonadal men with human chorionic gonadotropin alone
}

\author{
Marion Depenbusch, Sigrid von Eckardstein, Manuela Simoni and Eberhard Nieschlag \\ Institute of Reproductive Medicine of the University, Domagkstr. 11, D-48149 Münster, Germany \\ (Correspondence should be addressed to E Nieschlag; Email: nieschl@uni-muenster.de)
}

\begin{abstract}
Objective: It is generally accepted that both gonadotropins LH and FSH are necessary for initiation and maintenance of spermatogenesis. We investigated the relative importance of FSH for the maintenance of spermatogenesis in hypogonadotropic men.

Subjects and methods: 13 patients with gonadotropin deficiency due to idiopathic hypogonadotropic hypogonadism (IHH), Kallmann syndrome or pituitary insufficiency were analyzed retrospectively. They had been treated with gonadotropin-releasing hormone (GnRH) $(n=1)$ or human chorionic gonadotropin/human menopausal gonadotropin $(\mathrm{hCG} / \mathrm{hMG})(n=12)$ for induction of spermatogenesis. After successful induction of spermatogenesis they were treated with hCG alone for maintenance of secondary sex characteristics and in order to check whether sperm production could be maintained by hCG alone. Serum LH, FSH and testosterone levels, semen parameters and testicular volume were determined every three to six months.

Results: After spermatogenesis had been successfully induced by treatment with GnRH or hCG/hMG, hCG treatment alone continued for 3-24 months. After 12 months under hCG alone, sperm counts decreased gradually but remained present in all patients except one who became azoospermic. Testicular volume decreased only slightly and reached $87 \%$ of the volume achieved with hCG/ hMG. During treatment with hCG alone, FSH and LH levels were suppressed to below the detection limit of the assay.

Conclusion: Once spermatogenesis is induced in patients with secondary hypogonadism by GnRH or $\mathrm{hCG} / \mathrm{hMG}$ treatment, it can be maintained in most of the patients qualitatively by hCG alone, in the absence of FSH, for extended periods. However, the decreasing sperm counts indicate that FSH is essential for maintenance of quantitatively normal spermatogenesis.
\end{abstract}

European Journal of Endocrinology 147 617-624

\section{Introduction}

In male hypogonadotropic hypogonadism testosterone therapy is sufficient for maturation and maintenance of secondary sex characteristics. For stimulation of spermatogenesis administration of gonadotropins is necessary. If pulsatile gonadotropin-releasing hormone $(\mathrm{GnRH})$ is not indicated or desired, human chorionic gonadotropin (hCG) is used as the source of luteinizing hormone (LH) activity to stimulate testosterone secretion by Leydig cells, whereas human menopausal gonadotropin (hMG) is used as the source of folliclestimulating hormone (FSH) (1). More recently, recombinant gonadotropins have also been used clinically $(2-4)$.

Several animal studies have investigated the relative contributions of both gonadotropins for induction and maintenance of spermatogenesis (5-10). However, maintenance of spermatogenesis in rats, non-human primates and humans might be species-specifically regulated. Earlier case reports showed that spermatogenesis can be maintained in idiopathic hypogonadotropic hypogonadism (IHH) patients with hCG alone (11), and Vicari (1992) demonstrated that spermatogenesis can even be induced with hCG alone in IHH patients, but the addition of hMG improved the sperm output in some patients (12). Therefore FSH and LH/ testosterone in combination and alone seem to be sufficient to maintain spermatogenesis to a certain extent (13).

Hypogonadotropic hypogonadism $(\mathrm{HH})$ provides a pathological situation which allows the relative contributions of LH and FSH for human spermatogenesis to be studied, as these patients do not produce gonadotropins, and differential substitution of either hCG or hMG is possible. In this study we demonstrate that spermatogenesis in $\mathrm{HH}$ patients, once induced by administration of $\mathrm{GnRH}$ or hCG/hMG, can in most of 


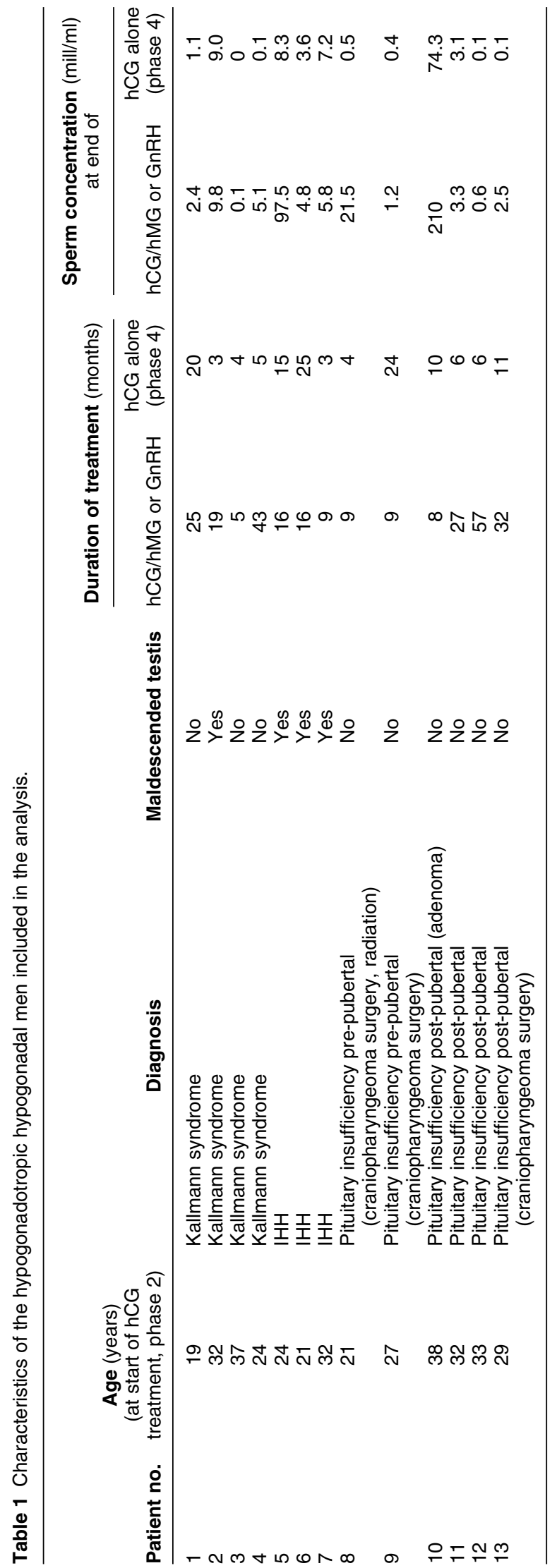

the patients be maintained qualitatively with hCG alone for extended periods.

\section{Subjects and methods}

\section{Subjects}

In an open uncontrolled retrospective trial we studied 13 of all patients with secondary hypogonadism who were treated with $\mathrm{GnRH}$ or hCG/hMG for induction of spermatogenesis. The selection criterion for these 13 patients was, that after spermatogenesis had been successfully induced, they were treated with hCG instead of testosterone preparations for the maintenance of secondary sex characteristics. Gonadotropin deficiency resulted from IHH $(n=3)$, Kallmann syndrome $(n=4)$ or pituitary insufficiency (pre-pubertal: $n=2$, post-pubertal: $n=4$ ). In most cases pituitary insufficiency was due to pituitary tumors (Table 1). Some patients had a history of treated unilateral or bilateral maldescended testes: all patients with $\mathrm{IHH}$, one patient with Kallmann syndrome and one with post-pubertal pituitary insufficiency. Clinical examinations had been performed at intervals of 3 to 6 months. Patients' ages ranged from 19 to 38 years at the beginning of treatment, all were azoospermic and had serum LH and FSH levels below the normal range.

\section{Treatment}

Patients with secondary hypogonadism can be effectively treated with pulsatile GnRH or hCG/hMG in order to induce spermatogenesis (14). In this study one patient received pulsatile GnRH $(5 \mu \mathrm{g} / 120 \mathrm{~min})$ and 12 patients received $\mathrm{hCG} / \mathrm{hMG}$ therapy according to common clinical guidelines with $3 \times 150 \mathrm{IU}$ hMG subcutaneously per week and individually adapted hCG doses ranging from $2 \times 500$ to 2500 IU per week (1). After successful induction of spermatogenesis testosterone production was maintained with hCG instead of substituting testosterone. Treatment was continued as long as patients preferred hCG over testosterone substitution. For analysis of data we differentiated 4 different phases of treatment.

Phase 1 - testosterone treatment Patients received either testosterone enanthate (Testoviron-Depot-250, Schering, Berlin, Germany) $250 \mathrm{mg} / 14-28$ days intramuscularly, or transdermal testosterone (Testoderm 15, Ferring, Kiel, Germany) $15 \mathrm{mg} /$ day applied on the scrotum.

Phase 2 - hCG alone treatment (only in those patients subsequently treated with hCG/hMG) Patients received 500-2500 IU hCG (Choragon 1500, Ferring; Primogonyl, Schering; Pregnesin 5000, Serono, Unterschleißheim, Germany; Predalon 500, 
Organon, Oberschleißheim, Germany), twice per week subcutaneously.

Phase 3 - hCG/hMG treatment While continuing the same dosage of hCG, each patient simultaneously received $150 \mathrm{IU}$ hMG (Menogon, Ferring; Fertinorm HP 150, Serono; Gonal-F 150, Serono), three times weekly subcutaneously. Pulsatile GnRH treatment: the patient received $5 \mu \mathrm{g} \mathrm{GnRH} / 120 \mathrm{~min}$ subcutaneously using a Zyklomat pulse set (Lutrelef, Ferring).

Phase 4 - hCG alone treatment Immediately after successful induction of spermatogenesis with GnRH or hCG/hMG or achievement of pregnancy, patients continued to receive individual doses of hCG (500-2500 IU twice weekly) subcutaneously, adjusted to trough serum testosterone levels to be maintained in the normal range.

\section{Methods}

During the course of treatment, physical and clinical control examinations such as semen analysis, determination of testicular volume and hormone analysis were performed every three to six months. Blood samples were drawn for hormone measurements as well as hematology and clinical chemistry (data not shown).

Hormone analysis LH and FSH were analyzed by immunofluorometric assays (Delfia, Wallac, Freiburg, Germany). The lower detection limits were $0.12 \mathrm{IU} / \mathrm{l}$ for $\mathrm{LH}$ and $0.25 \mathrm{IU} / \mathrm{l}$ for $\mathrm{FSH}$. The normal range is 2-10 IU/l for LH and 1-7 IU/l for FSH. Interassay variance of all assays did not exceed $6.5 \%$ for $\mathrm{LH}$ and $4.5 \%$ for FSH. Serum testosterone was determined using a commercial fluoroimmunoassay (Delfia, Wallac). The lower detection limit was $0.5 \mathrm{nmol} / \mathrm{l}$. The normal range for testosterone is above $12 \mathrm{nmol} / \mathrm{l}$. Interassay variance of all assays did not exceed $12.9 \%$.

Semen analysis Semen parameters were analyzed according to WHO guidelines (15) and subjected to internal (16) and external (17) quality control.

Testicular volume Determination of testicular volume was performed by palpation and sonography using a 7.5 Mhz sector scan until 1999 (Sonoline Versa Pro, Siemens, Erlangen, Germany), thereafter using a high
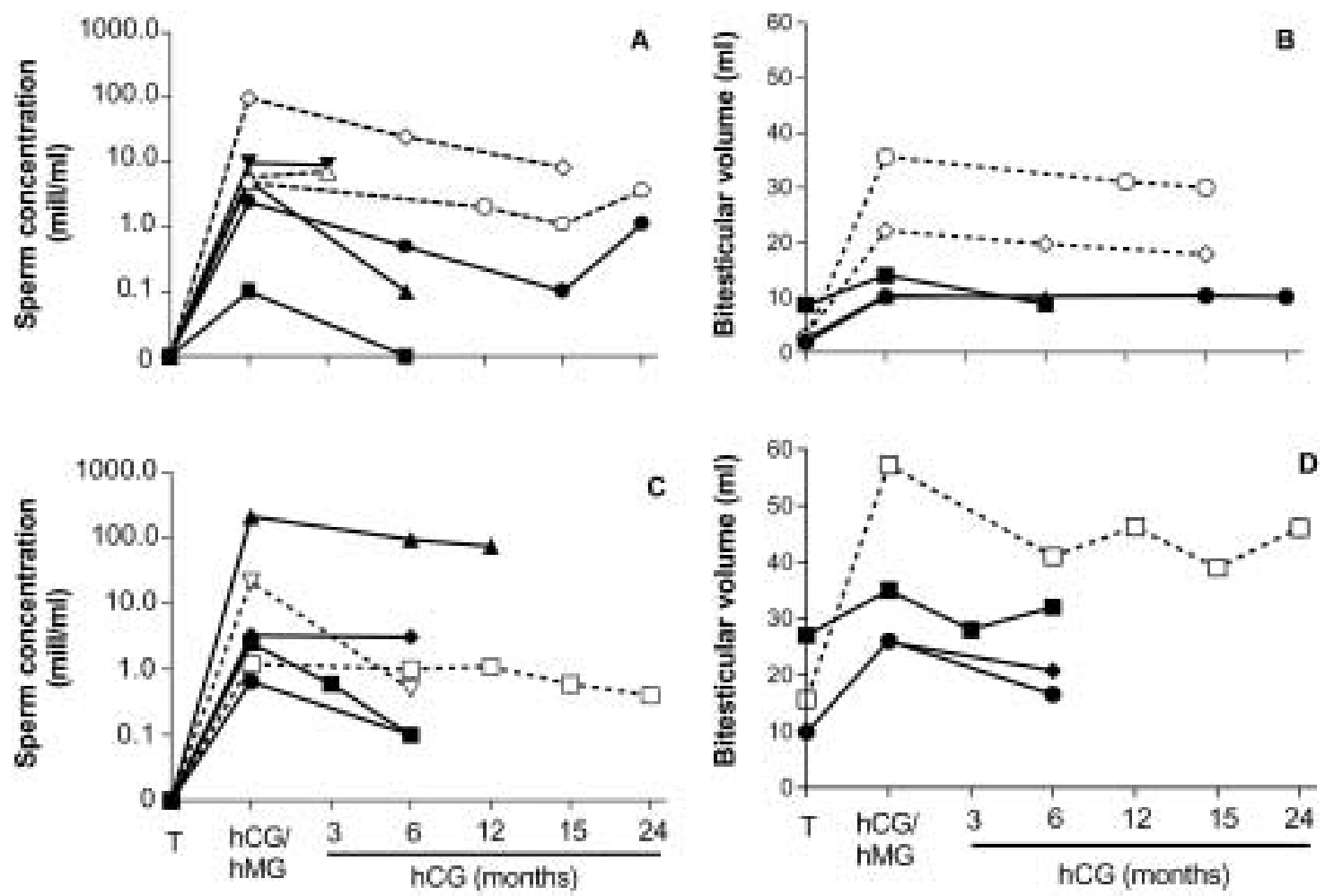

Figure 1 Individual sperm concentrations and testicular volumes. (A) Individual sperm concentrations in men with IHH ( $n=3$, open symbols) or Kallmann syndrome ( $n=4$, solid symbols) under hCG/hMG or hCG alone. (B) Individual testicular volumes in men with $\mathrm{IHH}$ ( $n=2$, open symbols) or Kallmann syndrome $(n=2$, solid symbols) under hCG/hMG or hCG alone. (C) Individual sperm concentrations in men with pre-pubertal ( $n=2$, open symbols) or post-pubertal $(n=4$, solid symbols) pituitary insufficiency under hCG/hMG or hCG alone. (D) Individual testicular volumes in men with pre-pubertal $(n=1$, open symbols) or post-pubertal $(n=3$, solid symbols) pituitary insufficiency under hCG/hMG or hCG alone. T, testosterone. 
frequency $7.5 \mathrm{Mhz}$ convex scanner (Ultrasound Scanner Type 2002 ADI, B\&K Medical, Gentofte, Denmark). The procedure for calculation of testicular volume has been described previously $(18,19)$.

\section{Statistical analysis}

Statistical analysis was performed using GraphPad Prism software (version 2.01). Results are given as means \pm S.D. Differences between groups were tested by Mann-Whitney rank sum test.

\section{Results}

\section{Treatment}

Patients had been pretreated with testosterone (phase 1) for a median duration of 20 months with a minimum of 5 months and a maximum of 14 years. Treatment with hCG alone (phase 2) lasted for a median time of 3.5 months with a minimum of 1 month and a maximum of 6 months. Induction of spermatogenesis with pulsatile GnRH or hCG/hMG (phase 3) lasted for a median time of 16 months with a minimum of five months and a maximum of 57 months (individual treatment periods are given in Table 1). As previously reported (14), the testicular volume at the beginning of therapy was a significant predictor $(P=0.017)$ for the necessary length of hCG/hMG or GnRH treatment until spermatogenesis was induced. At the end of GnRH or hCG/hMG treatment patients had a median sperm concentration of 3.3 millions $/ \mathrm{ml}(\mathrm{mill} / \mathrm{ml})$ with a minimum of $0.1 \mathrm{mill} / \mathrm{ml}$ and a maximum of $210 \mathrm{mill} / \mathrm{ml}$. Bitesticular volumes had increased initially from a mean volume of $6.5 \mathrm{ml}$ (minimum: $2.4 \mathrm{ml}$, maximum: $40 \mathrm{ml}$ ) to a mean of $24.0 \mathrm{ml}$ (minimum: $10.2 \mathrm{ml}$, maximum: $57.2 \mathrm{ml}$ ). In four patients

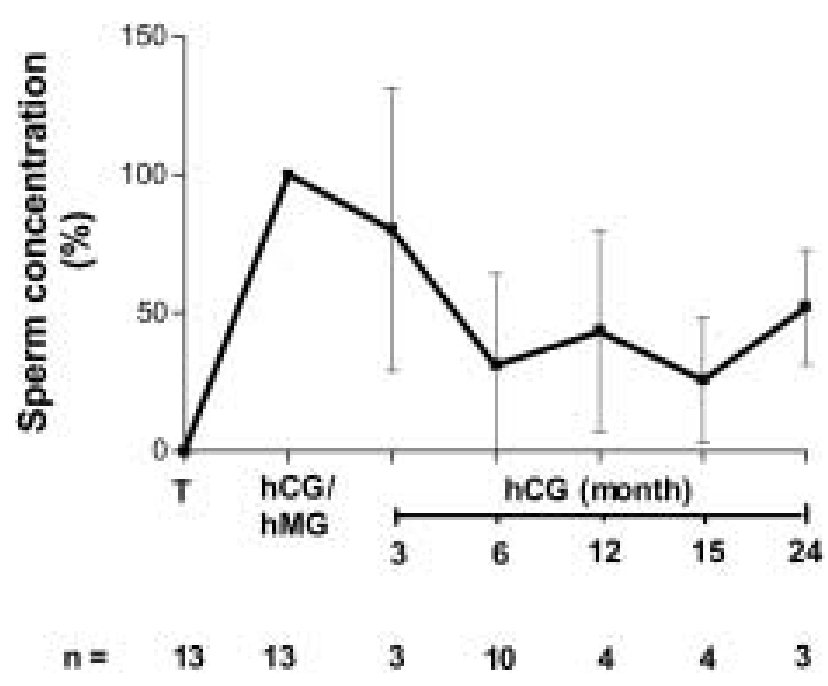

Figure 2 Sperm concentration under hCG alone expressed as a percentage of the last sample under hCG/hMG. T, testosterone. not desiring pregnancy, induction of spermatogenesis was terminated after sperm had appeared in the ejaculate. Five of nine patients successfully induced pregnancies. These results are comparable to those published previously on a larger cohort (14).

After GnRH or hCG/hMG treatment, testosterone production was maintained with administration of hCG alone (phase 4). The median treatment duration was 10 months with a minimum of three and a maximum of 25 months (individual treatment periods are given in Table 1). hCG alone maintained spermatogenesis at a lower concentration in all patients, with the exception of one who became azoospermic after four months. This patient only achieved a sperm concentration of $0.1 \mathrm{mill} / \mathrm{ml}$ after five months treatment with hCG/hMG. After six months semen parameters of 10 patients were analyzed. The median sperm concentration was $0.5 \mathrm{mill} / \mathrm{ml}$ with a minimum of $0.1 \mathrm{mill} / \mathrm{ml}$ and a maximum of $94 \mathrm{mill} / \mathrm{ml}$ (Fig. 1A and $1 \mathrm{C})$. When considering the maximum response to GnRH or hCG/hMG treatment as $100 \%$, after six months treatment with hCG alone sperm concentration was $31 \%$ of the concentration achieved with $\mathrm{GnRH}$ or hCG/hMG (Fig. 2). Testicular volume achieved at the end of $\mathrm{GnRH}$ or hCG/hMG treatment was also considered to be equal to $100 \%$ in each individual. After six months with hCG alone the testicular volume of seven patients was determined and reached $80 \%$ of maximum (Fig. 3).

After 12 months with hCG alone, semen parameters and testicular volume of four patients were available for analysis. The median sperm count was $1.55 \mathrm{mill} / \mathrm{ml}$ with a minimum of $0.1 \mathrm{mill} / \mathrm{ml}$ and a maximum of $74.3 \mathrm{mill} / \mathrm{ml}$ (Fig. 1A and 1B). Expressed as a percentage of the maximum response to GnRH or hCG/hMG, the mean sperm concentration was $43 \%$ (Fig. 2) and the mean testicular volume was $87 \%$ (Fig. 3).

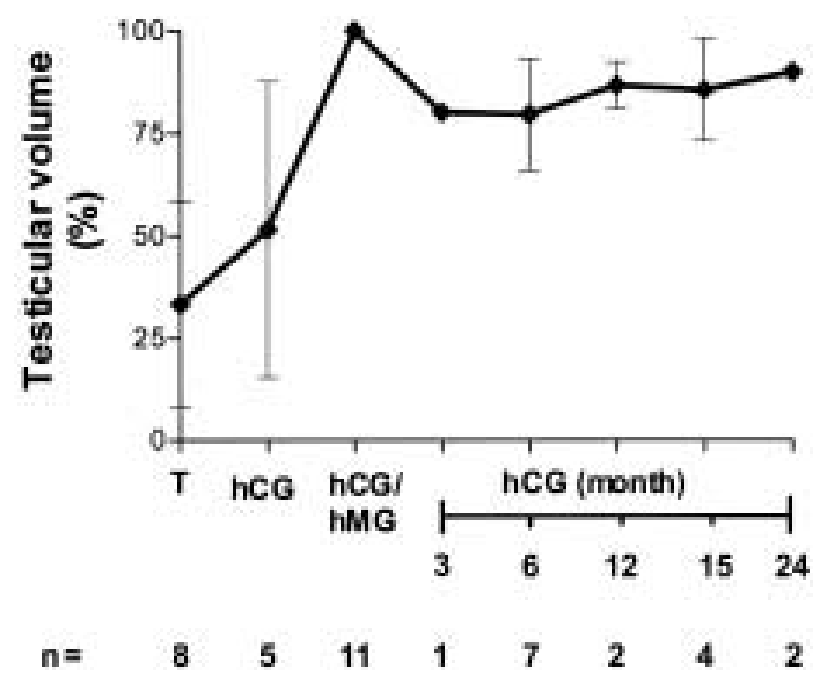

Figure 3 Bitesticular volume under hCG alone expressed as a percentage of the last value under hCG/hMG. T, testosterone. 
After 15 months with hCG alone semen parameters of four patients and testicular volume of five patients were available for analysis. The median sperm count was $1.25 \mathrm{mill} / \mathrm{ml}$ with a minimum of $0.1 \mathrm{mill} / \mathrm{ml}$ and a maximum of $8.3 \mathrm{mill} / \mathrm{ml}$ (Fig. 1A and 1B). Expressed as a percentage of the maximum response under GnRH or hCG/hMG, the mean sperm concentration was still $25.6 \%$ (Fig. 2) and the mean testicular volume was $86 \%$ (Fig. 3).

After 24 months with hCG alone, semen parameters and testicular volume of three patients were available for analysis. The median sperm count was $1.7 \mathrm{mill} / \mathrm{ml}$ with a minimum of $0.4 \mathrm{mill} / \mathrm{ml}$ and a maximum of $3.6 \mathrm{mill} / \mathrm{ml}$ (Fig. 1A and 1B). Expressed as a percentage of the maximum response to $\mathrm{GnRH}$ or hCG/hMG, the mean sperm concentration was $51.9 \%$ (Fig. 2) and the mean testicular volume was $90 \%$ (Fig. 3).

Four of the thirteen patients included are currently still under hCG treatment. The others stopped hCG treatment because they had no current wish for a child and wanted to use testosterone treatment to avoid any other method of contraception or because they preferred the application intervals of testosterone injections. One patient wished to achieve paternity and therefore added hMG again.

Comparing the different patient groups there was no obvious difference in the ability to maintain sperm production during treatment with hCG alone. The patients with Kallmann syndrome tended to have lower sperm concentrations and testicular volumes, but this was
A

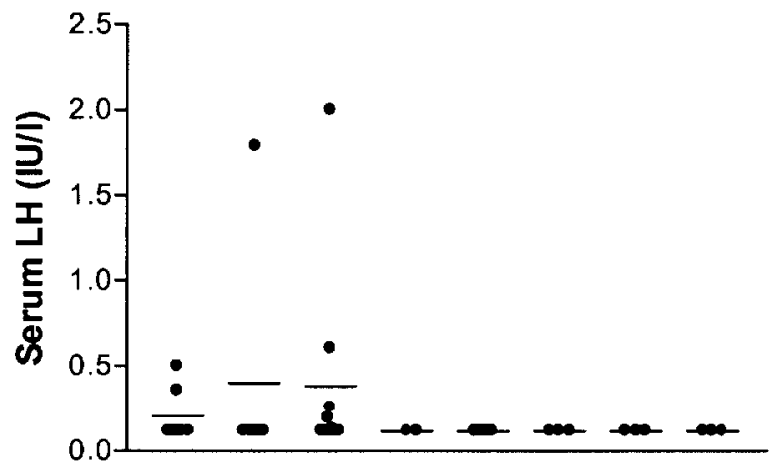

B

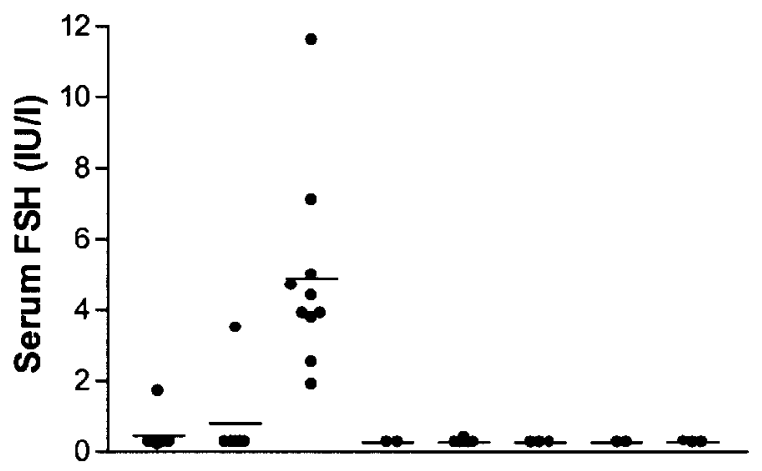

C

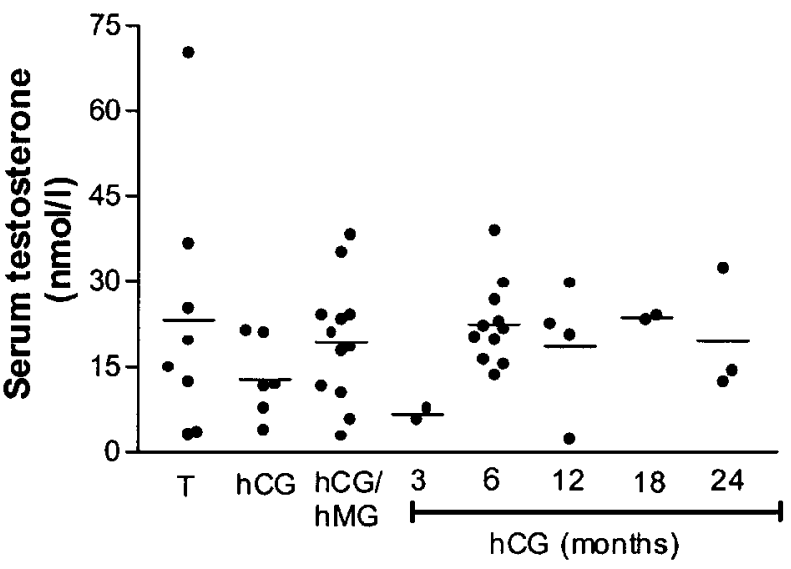

$\mathbf{n}=$

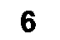

12
2
11

\section{detection limit}

detection limit
Figure 4 Serum hormone levels in individual patients (the bar shows the mean value). (A) Serum LH in men with secondary hypogonadism treated with $\mathrm{hCG} / \mathrm{hMG}$ or $\mathrm{hCG}$ alone (patient treated with pulsatile $\mathrm{GnRH}$ excluded). Normal range: $2-10 \mathrm{IU} / \mathrm{l}$.

(B) Serum FSH in men with secondary hypogonadism treated with $\mathrm{hCG} / \mathrm{hMG}$ or $\mathrm{hCG}$ alone (patient treated with pulsatile $\mathrm{GnRH}$ excluded). Normal range: $1-7 \mathrm{IU} / \mathrm{l}$.

(C) Serum testosterone in men with secondary hypogonadism treated with hCG/hMG or pulsatile $\mathrm{GnRH}$ and then with hCG alone. Normal range: $>12 \mathrm{nmol} / \mathrm{l}$. T, testosterone. 
not statistically significant. There was also no correlation of the testicular volume or the gonadotropin levels at the beginning of therapy or the treatment duration (neither phase 3 nor phase 4) with the maintained sperm concentrations. However, this might be due to the small patient number in the groups.

\section{Hormones}

Prior to treatment with GnRH or hCG/hMG all patients had serum FSH and LH levels around the detection limit (FSH: $0.4 \pm 0.5 \mathrm{IU} / \mathrm{l}, \mathrm{LH}: 0.2 \pm 0.1 \mathrm{IU} / \mathrm{l}$ ); testosterone levels were in the normal range $(19.9 \pm$ $21.6 \mathrm{nmol} / \mathrm{l})$. One patient had detectable serum $\mathrm{LH}$ and FSH levels during treatment with hCG alone (phase 2) indicating a partial gonadotropin secretion in this patient. With hCG/hMG treatment testosterone levels remained in the normal range (19.4士 $10.7 \mathrm{nmol} / \mathrm{l})$, FSH levels rose to the normal range $(4.9 \pm 2.7 \mathrm{IU} / \mathrm{l})$, LH levels were around the detection limit $(0.4 \pm 0.6 \mathrm{IU} / \mathrm{l})$ except in one patient who had detectable LH, again probably due to partial gonadotropin secretion. The patient treated with pulsatile GnRH had a serum FSH value of $6.8 \mathrm{IU} / \mathrm{l}$ and a serum LH value of $10.7 \mathrm{IU} / \mathrm{l}$ and was excluded from the gonadotropin analysis in Fig. 4A and 4B. FSH levels decreased after patients discontinued $\mathrm{GnRH}$ or hMG and continued with hCG alone and fell back to below the detection limit (FSH $<0.25 \mathrm{IU} / \mathrm{l}$, Fig. 4B). $\mathrm{LH}$ levels were also below the detection limit $(\mathrm{LH}<0.12 \mathrm{IU} / \mathrm{l}$, Fig. 4A). Testosterone levels were generally in the normal range (testosterone $>12 \mathrm{nmol} / \mathrm{l}$ ). If they were below the normal range, this was mostly due to the period of time since the last application of testosterone or hCG. In one patient an insufficient compliance was possible, and in another one the dosage of hCG had to be adjusted (Fig. 4C).

\section{Discussion}

Male hypogonadotropic hypogonadism (HH), characterized by the absence of endogenous gonadotropin secretion, is a convenient model to assess the effects of $\mathrm{LH}$ and $\mathrm{FSH}$ on human spermatogenesis. In this retrospective analysis of $13 \mathrm{HH}$ patients we demonstrate that spermatogenesis can, in most of the patients, be maintained qualitatively but not quantitatively for extended periods by treatment with hCG alone in the absence of FSH, once it had been induced by GnRH or hCG/hMG therapy, as case reports had shown previously (11).

Studies in rodents, non-human primates and humans have shown that $\mathrm{LH} /$ testosterone is essential for spermatogenesis $(7,8,10,20-24)$, while the role of FSH in the maintenance of spermatogenesis remains controversial. In monkeys treated with a GnRH antagonist to suppress pituitary gonadotropin production, the administration of FSH alone was sufficient to maintain spermatogenesis, at least in part (25). Other studies are quoted supporting the hypothesis that spermatogenesis can be completed in the absence of FSH. The FSH $\beta$ subunit knockout mouse has a qualitatively normal production of sperm in the absence of FSH (26), and mice with a disruption of the FSH receptor also produce qualitatively normal sperm (27). Active immunization against FSH (5) and the FSH receptor in monkeys (28) decreased but did not completely deplete spermatogenesis. However, nonspecific effects of the immunoneutralization procedure are possible (29). It has also previously been described that there are certain differences in spermatogenetic pathways in rodents and primates (29). Recently, two men with a mutation in the FSH $\beta$ subunit gene and azoospermia have been reported $(30,31)$. These cases demonstrate the essential role of FSH for the initiation of spermatogenesis but add little information about the role of FSH in the maintenance of spermatogenesis. In an experimental study carried out with normal men, Matsumoto et al. (32) demonstrated that normal levels of FSH are not required for the maintenance of qualitatively normal spermatogenesis but are required for the maintenance of quantitatively normal spermatogenesis. However, it has been suggested that FSH could still be present in this experimental setting as suppression of gonadotropins was achieved with testosterone. Evidence from the non-human primate indicates that even during testosterone application for several months small amounts of biologically active FSH remain present (33). In normal men participating in contraceptive studies it is similarly very difficult to suppress FSH secretion completely (34). This has recently been confirmed using a more sensitive FSH assay (35).

In the testis, LH acts primarily on Leydig cell testosterone production. In the hypogonadal (hpg) mouse, which is completely deprived of gonadotropins due to major deletions in the GnRH gene, it could be shown that application of testosterone is sufficient to induce spermatogenesis and that the threshold of testosterone for maintenance is comparably low (36). In monkeys it has been shown that after surgical hypophysectomy complete but quantitatively reduced spermatogenesis could be maintained with testosterone therapy alone (37). In the human, administration of testosterone after induction of azoospermia with $\mathrm{GnRH}$ antagonists resulted in a rebound of sperm production. However, this rebound was only observed after the GnRH antagonist had been withdrawn, leaving the possibility of a short-term increase in LH and/or FSH (38). Earlier case reports on two patients with hypogonadotropic hypogonadism showed that spermatogenesis induced by hCG/hMG could be maintained by hCG alone (11). Long-term treatment with hCG alone in $\mathrm{HH}$ patients also effectively induced and maintained spermatogenesis (12). However, the completeness of absence of 
gonadotropins in these cases (sporadic pulses?) remained unclear and the addition of hMG improved sperm function and output in some patients (12). There might be a residual FSH secretion in patients with HH. Notwithstanding, during treatment with hCG alone our patients all had FSH levels below the detection limit of our assay $(<0.25 \mathrm{IU} / \mathrm{l}$, Fig. 4B).

Concerning the wide range in sperm concentration observed in this retrospective analysis, the following aspects have to be considered: there are different causes of $\mathrm{HH}$ (anatomical lesions, genetic/idiopathic causes). Therefore the age of onset (pre- versus postpubertal) and the extent of pituitary failure (complete/partial) may lead to differences in the response to treatment. In cases of acquired $\mathrm{HH}$, a more rapid improvement in spermatogenesis in response to gonadotropin therapy is expected compared with the idiopathic/genetic variants, presumably because testicular development had been normal before the onset of disease (39). In our retrospective analysis there is no obvious difference in sperm concentrations achieved by men with different causes of $\mathrm{HH}$, consistent with findings from our larger series of $\mathrm{HH}$ patients (14). Another explanation for the wide range of sperm concentration might be pre-existing (i.e. independent of gonadotropins) fertility problems, a history of maldescended testes and the duration of treatment with hCG/hMG.

In summary, FSH and LH/testosterone in combination and alone are able to maintain spermatogenesis to a certain extent. For quantitatively normal spermatogenesis both gonadotropins are required (13). Consistent with these findings, our current study demonstrates that, in patients with $\mathrm{HH}$, once spermatogenesis has been induced by gonadotropin therapy, it can in most of the patients be maintained qualitatively, although quantitatively reduced, with hCG alone at least for some time in the absence of FSH. This has implications for the cost/effectiveness of this treatment since obviously expensive FSH preparations can be eliminated for longer periods once spermatogenesis has been induced.

\section{Acknowledgements}

We thank PD Dr Maria Byrne and Susan Nieschlag, MA for language editing of the manuscript.

\section{References}

1 Behre HM, Nieschlag E, Meschede D \& Partsch CJ. Diseases of the hypothalamus and the pituitary gland. In Andrology: Male Reproductive Health and Dysfunction, edn 2, pp 125-142. Eds E Nieschlag \& HM Behre. Berlin: Springer-Verlag, 2000.

2 Liu PY, Turner L, Rushford D, McDonald J, Baker GHW, Conway AJ et al. Efficacy and safety of recombinant human follicle stimulating hormone (Gonal-F) with urinary human chorionic gonadotropin for induction of spermatogenesis and fertility in gonadotropin-deficient men. Human Reproduction $1999 \mathbf{1 4}$ $1540-1545$.

3 Young J, Couzinet B, Chanson P, Brailly S, Loumaye E \& Schaison G. Effects of human recombinant luteinizing hormone and follicle-stimulating hormone in patients with aquired hypogonadotropic hypogonadism: study of Sertoli and Leydig cell secretions and interactions. Journal of Clinical Endocrinology and Metabolism 200085 3239-3244.

4 Mulligan T, Iranmanesh A \& Veldhuis JD. Pulsatile i.v. infusion of recombinant human LH in leuprolide-suppressed men unmasks impoverished Leydig-cell secretory responsiveness to midphysiological LH drive in the ageing male. Journal of Clinical Endocrinology and Metabolism 200186 5547-5553.

5 Srinath BR, Wickings EJ, Witting C \& Nieschlag E. Active immunization with follicle-stimulating hormone for fertility control: a 4 1/2-year study in male rhesus monkeys. Fertility and Sterility $1983 \mathbf{4 0} 110-117$.

6 Mougdal NR, Ravindranath N, Murthy GS, Dighe RR, Aravindan GR \& Martin F. Long-term contraceptive efficacy of vaccine of ovine follicle-stimulating hormone in male bonnet monkeys (Macaca radiata). Journal of Reproduction and Fertility 199296 91-102.

7 Jeyakumar M, Suresh R, Krishnamurthy HN \& Mougdal NR. Changes in testicular function following specific deprivation in the adult male rabbit. Journal of Endocrinology $1995 \mathbf{1 4 7}$ 111-120.

8 Suresh R, Medhamurthy R \& Mougdal NR. Comparative studies on the effects of specific immunoneutralization of endogenous FSH or LH on testicular germ cell transformations in the adult bonnet monkey (Macaca radiata). American Journal of Reproductive Immunology 199534 35-43.

9 Graf KM, Dias JA \& Griswold MD. Decreased spermatogenesis as the result of an induced autoimmune reaction directed against the gonadotropin receptors in male rats. Journal of Andrology 199718 174-185.

10 Lei ZM, Mishra S, Zou W, Xu B, Foltz M, Li X et al. Targeted disruption of luteinizing hormone/human chorionic gonadotropin receptor gene. Molecular Endocrinology 200115 184-200.

11 Johnsen SG. Maintenance of spermatogenesis induced by hMG treatment by means of continuous hCG treatment in hypogonadotropic men. Acta Endocrinologica $197889763-769$.

12 Vicari E, Mongioi A, Calogero AE, Moncada ML, Sidoti G, Polosa P et al. Therapy with human chorionic gonadotropin alone induces spermatogenesis in men with isolated hypogonadotropic hypogonadism: long term follow-up. International Journal of Andrology $199214320-329$.

13 Nieschlag E, Simoni M, Gromoll J \& Weinbauer GF. Role of FSH in the regulation of spermatogenesis: clinical aspects. Clinical Endocrinology $1999 \mathbf{5 1} 139-146$.

14 Büchter D, Behre HM, Kliesch S \& Nieschlag E. Pulsatile GnRH or human chorionic gonadotropin/human menopausal gonadotropin as effective treatment for men with hypogonadotropic hypogonadism: a review of 42 cases. European Journal of Endocrinology $1998139298-303$.

15 WHO Laboratory Manual for the Examination of Human Semen and Semen-Cervical Mucus Interaction, edns 1, 2, 3 and 4. Singapore: Press Concern 1980, Cambridge: University Press 1987, 1992 and 1999.

16 Cooper TG, Neuwinger J, Bahrs S \& Nieschlag E. Internal quality control of semen analysis. Fertility and Sterility $1992 \mathbf{5 8}$ 172-178.

17 Cooper TG, Atkinson AD \& Nieschlag E. Experience with external quality control in spermatology. Human Reproduction 199914 765-769.

18 Behre HM, Yeung CH, Holstein AF, Weinbauer GF, Gassner P \& Nieschlag E. Diagnosis of male infertility and hypogonadism. In Andrology: Male Reproductive Health and Dysfunction, edn 2, pp 89-124. Eds E Nieschlag \& HM Behre. Berlin: SpringerVerlag, 2000.

19 Behre HM, Kliesch S, Schaedel F \& Nieschlag E. Clinical relevance of scrotal and transrectal ultrasonography in andrological 
patients. International Journal of Andrology 199518 (Suppl 2) $27-31$.

20 Weinbauer GF \& Nieschlag E. The role of testosterone in spermatogenesis. In Testosterone Action: Deficiency, Substitution, edn 2, ch 4, pp 143-168. Eds E Nieschlag \& HM Behre. Berlin: Springer-Verlag, 1990.

21 Weinbauer GF \& Nieschlag E. The Leydig cell as a target for male contraception. In The Leydig Cell, pp 629-662. Eds AH Payne, MP Hardy \& LD Russell. Vienna: Cache River Press, 1996.

22 O'Donnell L, McLachlan RI, Wreford NG, de Kretser DM \& Robertson DM. Testosterone withdrawal promotes stage-specific detachment of round spermatids from the rat seminiferous epithelium. Biology of Reproduction 199655 895-901.

23 Awoniyi CA, Zirkin BR, Chandrashekar V \& Schlaff WD. Exogenously administered testosterone maintains spermatogenesis quantitatively in adult rats actively immunized against gonadotropin-releasing hormone. Endocrinology $1992 \mathbf{1 3 0}$ 3283-3288.

24 Weiss J, Axelrod L, Whitcomb RW, Harris PE, Crowley WF \& Jameson JL. Hypogonadism caused by a single amino acid substitution in the subunit of luteinizing hormone. New England Journal of Medicine 1992326 179-183.

25 Weinbauer GF, Behre HM, Fingscheidt U \& Nieschlag E. Human follicle-stimulating hormone exerts a stimulatory effect on spermatogenesis, testicular size and serum inhibin levels in the gonadotropin releasing hormone antagonist-treated nonhuman primate (Macaca fascicularis). Endocrinology $1991 \quad 129$ $1831-1839$.

26 Kumar TR, Wang Y, Lu N \& Matzuk MM. Follicle-stimulating hormone is required for ovarian follicle maturation but not male fertility. Nature Genetics 199715 201-204.

27 Krishnamurthy H, Danilovich N, Morales CR \& Sairam MR. Qualitative and quantitative decline in spermatogenesis of the follicle-stimulating hormone receptor knockout (FORKO) mouse. Biology of Reproduction 200062 1146-1159.

28 Moudgal NR, Sairam MR, Krishnamurthy HN, Sridhar S, Krishnamurthy $\mathrm{H}$ \& Khan $\mathrm{H}$. Immunization of male bonnet monkeys (Macaca radiata) with a recombinant $\mathrm{FSH}$ receptor preparation affect testicular function and fertility. Endocrinology 19971383065.

29 Plant TM \& Marshall GR. The functional significance of FSH in spermatogenesis and the control of its secretion in male primates. Endocrine Reviews 200122 764-786.

30 Lindstedt G, Nyström E, Matthews C, Ernest I, Janson PO \& Chatterjee K. Follitropin (FSH) deficiency in an infertile male due to FSH $\beta$ gene mutation. A syndrome of normal puberty and virilization but underdeveloped testicles with azoospermia, low FSH but high lutropin and normal serum testosterone concentrations. Clinical Chemistry and Laboratory Medicine 199836 $663-665$.

31 Phillip M, Arbelle JE, Segev Y \& Parvari R. Male hypogonadism due to a mutation in the gene for the $\beta$-subunit of folliclestimulating hormone. New England Journal of Medicine 199824 1729-1732.

32 Matsumoto AM, Karpas AE \& Bremner WJ. Chronic human chorionic gonadotropin administration in normal men: evidence that follicle-stimulating hormone is necessary for the maintenance of quantitatively normal spermatogenesis in man. Journal of Clinical Endocrinology and Metabolism 198662 1184-1192.

33 O’Donnell L, Narula A, Balourdos G, Gu YQ, Wreford NG, Robertson DM et al. Impairment of spermatogonial development and spermiation after testosterone-induced gonadotropin suppression in adult monkeys (Macaca fascicularis). Journal of Clinical Endocrinology and Metabolism 200186 1814-1822.

34 Kamischke A, Plöger D, Venherm S, von Eckardstein S \& Nieschlag E. Intramuscular testosterone undecanoate with or without oral levonorgestrel: a randomized placebo-controlled feasability study for male contraception. Clinical Endocrinology 200053 43-52.

35 Robertson DM, Pruysers E, Stephenson T, Pettersson K, Morton S \& McLachlan RI. Sensitive LH and FSH assays for monitoring low serum levels in men undergoing steroidal contraception. Clinical Endocrinology $200155331-339$.

36 Handelsman DJ, Spaliviero JA, Simpson JM, Allan CM \& Singh J. Spermatogenesis without gonadotropins: maintenance has a lower testosterone threshold than initiation. Endocrinology 1999 $1403938-3946$

37 Marshall GR, Jockenhövel F, Lüdecke D \& Nieschlag E. Maintenance of complete but quantitatively reduced spermatogenesis in hypophysectomized monkeys by testosterone alone. Acta Endocrinologica 1986113 424-431.

38 Behre HM, Kliesch S, Lemcke B, von Eckardstein S \& Nieschlag E. Suppression of spermatogenesis to azoospermia by combined administration of GnRH antagonist and 19-nortestosterone cannot be maintained by this non-aromatizable androgen alone. Human Reproduction 2001 16 2570-2577.

39 McLachlan RI. The endocrine control of spermatogenesis. Bailliere's Best Practice and Research in Clinical Endocrinology and Metabolism 200014 345-362.

Received 25 March 2002

Accepted 8 July 2002 